After the War, we must produce for export not the apparatus which other countries rightly wished to manufacture themselves, but commodities in which we have the technical ability to make ourselves supreme. By complete co-ordination of industrial organizations and research establishments electrical engineers can assist very materially, and the adoption of international standards must be considered. Mr. Taylor suggested uniformity of design for utility electrical products in common use both in the industrial and domestic fields. Such a standard, to be effective, would need to have behind it the authority of the British Standards Institution, and its adoption might even need legislative action. Manufacturers would be encouraged to adopt these standard commodities as their first line of production, and in consequence they would ultimately replace the many specialized products now on the market.

\section{Arterial Road Lighting}

THE arterial road connecting Toronto and Niagara Falls, known as Queen Elizabeth Way, is lighted by incandescent lamps in parallel over its whole length of 70 miles. Already the lighting installation enjoys the distinction of being the longest in the world, and no doubt it will be continued on the proposed 20mile extension of the highway to Fort Erie, making a total of 90 miles. In planning the installation provision was made for maximum silhouetting of obstacles. The Way consists of dual concrete tracks 20-23 ft. in width with an intervening strip of grass 28-30 ft. wide; the standard equipment comprises wooden poles, along the centre line of the grass, with welded cross-arms overhanging each traffic lane to the extent of $3 \mathrm{ft}$. The availability of cheap electric power from existing rural circuits operated by the Hydro-Electric Power Commission of Ontario seems to have been a determining factor in the adoption of incandescent lighting and parallel distribution. Sodium lamps are used to mark intersections. Distribution transformers of $15-\mathrm{kva}$. capacity feed the $115-\mathrm{v}$. lighting cables from the $2,300 \cdot v$. rural distribution network. The lamps are of 6,000 lumens, 400 watts, spaced $200 \mathrm{ft}$. apart, and maintenance is by group replacement twice a year. Operating experience and costs from this installation should be of material assistance in planning the general lighting of arterial roads.

\section{Discovery of Smithfield Industries in Kenya}

The September-October number of Mun contains a letter which is of distinct importance to those who concern themselves with the problems of Stone Age Africa. It would seem certain that Archdeacon Owen has discovered in a rock-shelter in Kenya an early Smithfield industry, and that Prof. van Riet Lowe has agreed with his interpretation. Smithfield industries occur over large parts of South Africa, especially in the Free State, the material used for their manufacture being usually the local indurated shale which chips well. Scrapers, awls, beads, and occasionally a little pottery have been found. The range in time of the culture extends backwards from modern days to an unknown, but probably fairly remote, period as the later Smithfield industries show differences when compared with the earlier ones. Thus the plano-convex knife is an early tool type and does not recur in the more recent finds, while pottery seems to be absent from the earlier ones. In South Africa, too, there are regional differences in the industries which add to their complexity. But the main great problem has always been as to whether the Smithfield culture as a whole was an autochthonous growth in South Africa itself, engendered perhaps by culturecontacts; or whether it was not rather introduced into the subcontinent by migrations from the rorth. Archdeacon Owen's new discovery of Early Smithfield material-considered in fact to be even some. what older than the Early Smithfield of South Africa -in Kenya would suggest that the latter hypothesis is the correct one.

\section{Folk-lore of Alcoholism}

IN a paper on this subject (Brit. J. Inebriety, JulyOctober), Dr. J. D. Rolleston remarks that with the exception of Hovorka and Kronfeld's great work on comparative folk medicine no writers have dwelt at length on folk-lore in relation to alcoholism. He has therefore collected the folk-lore of this condition, as he has recently done in the case of general medicine, dermatology and pulmonary tuberculosis. His paper deals with the nomenclature, popular phraseology, superstitions and leecheraft connected with alcoholism and alcohol, the term 'leechcraft' being that commonly employed in the language of folk-lore to indicate popular methods of prevention and treatment. In a previous paper on "Alcoholism in Classical Antiquity" (Brit. J. Inebriety, 24, 101; 1927) he directed attention to the numerous synonyms for inebriated or bibulous persons, both in Greek and Latin, as well as in English, which contained about seventy such terms, only a minority of which could be called slang, whereas there are more than 280 slang synonyms for the word 'drink', 160 for the verb 'to drink', and 150 for various forms of intoxication. Popular interest in the consumption of alcohol, especially in excess, was further demonstrated by the great variety of similes connected with the subject. After dealing with the superstitions and popular errors connected with alcohol and alcoholism, which are legion, Dr. Rolleston discusses the popular methods of prevention and cure for inebriety, which he classifies under the headings of animal remedies, including coprotherapy, plant remedies, of which a large proportion are mentioned by Pliny, mineral remedies, invocation of patron saints and water.

\section{Tuberculosis and War}

According to an editorial in the August issue of the Statistical Bulletin of New York, tuberculosis is already on the increase in other countries than the United States, although the evidence is based only on provisional or fragmentary data. In England and Wales the death-rate among male civilians rose slightly in 1939 and in 1940 in both sexes. For males the death-rate from tuberculosis rose 13 per cent 